\title{
REPRESENTASI IDEOLOGI DAN KEKUASAAN DALAM BAHASA: KAJIAN TEKS MEDIA
}

\author{
Oleh: \\ Suharyo, Surono, Mujid F. Amin \\ Jurusan Sastra Indonesia Fakultas Ilmu Budaya Universitas Diponegoro \\ Jl. Prof. H. Soedarto, SH Tembalang Semarang 50275
}

\begin{abstract}
This article is based on the assumption that language is not in a social vacuum. Language is more than a set of words that merely linguistic, but also social. Therefore, the current linguistic research should take into account the social dimension in the analysis are critical, such as van Dijk's critical discourse analysis (CDA) research model. The critical discourse analysis research considering the text, context, social cognition, and analysis/social context. Research steps include: exposing the macro structure (thematic), superstructure (schematic), and microstructure consisting of semantics, syntax, stylistic, and rhetoric. Accordingly, this study uses the method read and record while research data has been collected from Suara Merdeka and Kompas newspaper. Finally concluded that the language represents the ideology and power (symbolic) both individual and communal.
\end{abstract}

Keywords: language, representation, ideology, power, critical discourse analysis.

\section{PENDAHULUAN}

Sejak tumbangnya rezim Soeharto pers mengalami perubahan yang sangat dahsyat. Kedahsyatan perubahan tersebut terlihat dari kegairahan, kebebasan, dan ketransparanan. Kegairahan ditandai dari begitu banyak media cetak baru bermunculan. Selain itu, para pengelola harian juga tampak "bersemangat" dalam memburu informasi dan menyajikannya dalam berita tanpa merasa takut dibreidel. Hal yang sangat berbeda dengan pers era ORBA. Menyangkut aspek kebebasan tampak dari begitu beragam "menu" berita.Sebab, dulu - di era ORBA - hanya ada "satu" macam berita, yaitu "pembangunan nasional". Tidak ada berita kerusuhan, bentrok antarwarga yang dianggapnya hanya akan mengganggu stabilitas (politik) nasional dan pembangunan nasional. Tidak mungkin peristiwa Poso, Tolikara, Syiah Madura, Ahmadiyah tersaji dalam berita (di era
Soeharto). Kini, atas nama kebebasan semua peristiwa tidak ada yang "tabu” untuk diberitakan. Ketransparansian juga menjadi salah satu ciri media massa di era sekarang ini. Pemuatan berita tentang penghinaan terhadap mentri, pejabat, bahkan kepada presiden bisa dijumpai dalam media massa dan media sosial. Lalu, pertanyaannya benarkah dunia pers di era reformasi ini bebas dari kepentingan?

Hidayat (dalam Sudibyo, 2001) menjelaskan bahwa pers di era Reformasi ini memang telah lepas dari otoriter ORBA, tetapi tidak berarti tanpa kepentingan. Pers di era sekarang ini juga "harus" diwaspadai. Sebab, berbagai kepentingan yang berada di balik pers tentu masih menjadi faktor ketidakotonomian pers, seperti modal, organisasi (pers), kultur, dan ideologi. Berbagai kepentingan tersebut lalu mewujud menjadi berita, sehingga entitas pers sekarang ini menjadi “ambivalen”. Dalam 
bagian, soal, perkara, peristiwa tertentu; pers (media massa) hadir menjadi corong Pemerintah. Pada bagian lain, pers/media massa hadir sebagai "penghakim dan penghukum" bagi pihak/kelompok tertentu; dan pada kesempatan lain, media massa/pers menjadi "provokator" konflik, bahkan tampil sebagai “mesin politik” bagi partai tertentu. Ini selaras dengan pandangan AWK (Analisis Wacana Kritis). Di dalam tuturan/teks apa pun, selalu tersembunyi di dalamnya aspek ideologi dan kekuasaan (lihat Eriyanto, 2011; Badara, 2012).

Dalam upayanya menguasai kognisi, persepsi, dan opini publik diperlukan piranti agar tampak sebagai suatu kewajaran dan piranti yang cocok adalah melalui simbol (bahasa). Mobilisasi simbol yang dilakukan penguasa/kelompok dominan bertujuan untuk mempertahankan kekuasaan (simbolik) melalui strategi hegemoni semantik (Ibrahim, 2006: 50; Suharyo, dkk: 2012). Dalam konteks ini lalu muncul pertarungan dan perebutan kekuasaan simbolik. Gejala tersebut dapat disiratkan lewat "perang media". "Perang” tersebut, misalnya dapat diketahui melalui lead berita di media massa, seperti "Pemerintah Kerahkan 23 Ribu Aparat Keamanan Untuk Menjaga Gedung KPU”, "Hatta Radjasa Biang Keladi Mafia Migas”, Putusan MK Lahirkan Raja-Raja Daerah”, Suami Pimpin Muhammadiyah, Istri Nahkodai Aisyiah”, "Mendagri tetap Siapkan Perppu", "Koruptor Bakal Dituntut Hukuman Mati”, "DPR Ancam Panggil Paksa Menteri ESDM", "Kemenkum dan HAM Ngotot Banding” " Muktamar NU Gaduh", "Masyarakat Kesal Tak Bertemu Bupati”, "Aturan Calon Tunggal Digugat”, "29 PWNU Tolak Pemaksaan AHWA”, "Partai Golkar Di Obok-Obok Pemerintah”.

Judul-judul berita di atas yang dimuat di media massatidak hanya bersifat linguistis dan semantik belaka. Akan tetapi, juduljudul di atas memuat ideologi tertentu. Sebab, jika dicermati lebih jauh; judul-judul berita di atas memuat “metastruktur”. Sebab, di atas apa yang tampak (strukturnya) terdapat universe of discourse yang “mengikat”teks berita/wacana tersebut. Dan wacana bukan hanya sekadar kumpulan kalimat, tetapi memuat world-view. Di balik berita juga sesungguhnya "tersembunyi" ideologi (pembicara/penulis). Sebab, berita di media massa (baca: surat kabar) merupakan representasi simbolis dan nilai suatu masyarakat (Badara, 2012: 5). Ideologi dalam konteks ini sebagaimana dikatakan Wareing (via Ibrahim, 2007: 54) memiliki makna yang luas, yaitu untuk menyebut keyakinan-keyakinan yang dirasakan logis dan "wajar" oleh orang-orang yang menganutnya. Dalam konteks ini ideologi tidak harus bermakna/ berkonotasi negatif (seperti ideologi Marxis, PKI, dll). Ideologi juga bisa dimaknai sebagai sebuah dialektika kekuasaan yang tidak seimbang (dominasimarginal). Althusser, malah lebih melihat ideologi sebagai praktik daripada sebagai sebuah idea (Eriyanto, 2011: 98).

Memperhatikan berbagai pemberitaan di atas menarik untuk dikaji, sebagaimana dikatakan Bourdieu bahwa sesungguhnya bahasa tidak berada di ruang hampa sosial, tetapi selalu dipengaruhi oleh berbagai kepentingan politik, ekonomi, sosial, budaya, dll. Jadi, pemilihan kata, kalimat, dan pemosisian letak pokok pembicaraan (Subjek) bukan hanya sekadar teknik jurnalistik, tetapi lebih dari itu sesungguhnya berkaitan dengan politik pemberitaan. Dan oleh sebab itu, teks/wacana berita memiliki kaitan dengan ideologi.Akan tetapi, untuk mengungkap ideologi di balik berita/teks tidaklah mudah (Badara, 2012: 6). Oleh karena itu, penelitian ini menjadi sangat relevan untuk menjawab dan atau mengungkap ideologi dan kekuasaan simbolik di balik pemberitaan yang ada di media massa.

Pertanyaan yang dicoba dijawab dalamtulisan ini adalah (1) adakah representasi ideologi dan kekuasaan simbolik di balik penggunaan bahasa? (2) Piranti-piranti linguistik apakah yang merepresentasikan ideologi dan kekuasaan 
simbolik dalam penggunaan bahasa tersebut? Lalu (3) adakah perbedaan pengungkapan antara kelompok (harian) satu dengan lainnya?

Tujuan tulisan ini menjelaskan (1) ada/tidaknya representasi ideologi dan kekuasaan simbolik di balik penggunaan bahasa, (2) mendeskrip-sikan piranti-piranti linguistik yang merepresentasikan ideologi dan kekuasaan simbolik dalam penggunaan bahasa tersebut? Lalu (3) menjelaskan perbedaan pengungkapan antara kelompok (harian ) satu dengan lainnya.

\section{ANALISIS WACANA KRITIS (AWK) \\ Karakterisitk}

Dalam analisis wacana kritis, wacana tidak dipahami semata sebagai studi bahasa. Analisis wacana memang menggunakan bahasa dalam teks untuk dianalisis, tetapi bahasa yang dianalisis di sini agak berbeda dengan studi bahasa dalam pengertian linguistik tradisional. Bahasa dianalisis bukan dengan menggambarkan semata dari aspek kebahasaan, tetapi juga menghubungkan dengan konteks. Konteks di sini berarti bahasa itu dipakai untuk tujuan dan praktik tertentu, termasuk di dalamnya praktik kekuasaan (Eriyanto, 2011).

Karakteristik analisis wacana kritis yang dipandang penting yaitu bahwa (1) wacana dipahami sebagai tindakan, (2) sangat mempertimbangkan konteks, seperti latar, situasi, peristiwa, dan kondisi. Wacana di sini dipandang, diproduksi, dimengerti, dan dianalisis pada suatu konteks tertentu, (3) historis berarti melihat bagaimana “sejarah" suatu wacana diproduksi dalam konteks tertentu dan tidak dapat dimengerti tanpa menyertakan konteks (sejarah) yang menyertainya, (4) kekuasaan,yaitu bahwasetiap wacana yang muncul, dalam bentuk teks, percakapan, atau apa pun, tidak dipandang sebagai sesuatu yang alamiah, wajar, dan netral; tetapi merupakan bentuk pertarungan kekuasaan, (5) Ideologi, yaitu bahwa setiapteks, percakapan, dan lainnya adalah bentuk dari praktik ideologi atau pencerminan dari ideologi tertentu.

\section{Kosakata dalam Konteks AWK}

Bahasa dilihat oleh Roger Fowler, dkk. (via Eriyanto, 2011) sebagai sistem klasifikasi. Bahasa menggambarkan bagaimana realitas dunia dilihat, memberi kemungkinan seseorang untuk mengontrol dan mengatur pengalaman pada realitas sosial. Menurutnya, kosakata pada dasarnya (1) membuat klasifikasi terhadap pihak yang berkuasan dan yang terkuasai/ terdominasi, (2) kosakata membantasi pandangan, (3) pertarungan wacana, (4) kosakata memarginalisasi (terhadap kelompok marginal).

\section{METODOLOGI \\ Sumber Data}

Penelitian ini mengambil sumber data dari media cetak yang terbit antara tahun 2014-2015, yaitu koran yang berskala nasional maupun lokal. Alasan pengambilan sumber data dari media cetak karena (1) mudah diperoleh, (2) dapat dikaji/diteliti secara berulang-ulang. Adapun koran/ media cetak yang dijadikan sumber data adalah Kompas dan Suara Merdeka dengan alasan (1) mewakili koran yang berskala nasional (Kompas) dan lokal (Suara Merdeka), (2) keduanya beroplah besar, dan (3) memiliki jangkauan pembaca dan daerah persebaran yang cukup luas.

Pengambilan sampel media massa yang terbit antara tahun 2014-2015 didasari alasan kendala/ keterbatan waktu, tenaga, dan kemampuan peneliti. Meskipun demikian, secara metodologis linguistik/komunikasi hal itu dapat dipertanggungjawabkan reliabilitas dan validitasnya karena menurut Sudaryanto (1994), Munawar (2008), Kriyantono (2012) data kebahasaan (relatif) bersifat homogen.

\section{Pengumpulan Data}

Pengumpulan data dilakukan dengan metode simak dilanjutkan dengan teknik catat. Metode simak dilakukan dengan cara (1) membaca dengan cermat wacana/teks 
berita pada harian Suara Merdeka dan Kompas misalnya yang memuat berita politik, sosial yang merepresentasikan ideology dan kekuasaan (simbolik), (2) meneliti aspek struktur bahasanya (pilihan kata, kosakata, kalimat, koherensi, aspek nalar, dan lain-lain), (3) mencermati hal-hal penting yang diberitakan/dideskripsikan oleh kedua media massa tersebut (misalnya penggambaran berita yang bias gender, rasis, dominasi-marginal, dan lain-lain.) Setelah itu, dilanjutan dengan teknik catat. Teknik catat dan atau unduh digunakan untuk (1) mencatat data yang sesuai dengan tujuan penelitian. Langkah selanjutnya adalah mengklasifikasikan data tersebut menjadi dua bagian, yaitu yang (a) merepresentasikan ideologi dan kekuasaan dan (b) mencatat fitur-fitur linguistik yang mencerminkan/merepresentasikan ideologi dan atau kekuasaan (simbolik).

\section{Analisis Data}

Dalam penelitian ini, data dianalisis dengan menggunakan metode analisis wacana kritis sebagaimana dikemukakan oleh van Dijk (via Badara,2012; Eriyanto, 2011) seperti ditunjukkan lewat bagan berikut ini. (Lihat Lampiran 1.)

\section{PEMBAHASAN HASIL}

Dari data yang terkumpul melalui sumber berita yang dimuat di harian Kompas dan Suara Merdeka diperoleh hasil sebagai berikut. Berikut salah satu contoh berita (data) yang dimuat pada harian K dan SM.

\section{Berita tentang Kasus Hambalang}

Berdasarkan model van Dijk uraian dilakukan sebagaimana dikemukakan dalam metodologi.

\section{Dari Aspek Tematik (Struktur Makro)}

Harian Suara Merdeka menulis di halaman pertama dengan judul "Uang Muka Mobil Anas dari SBY", sedangkan harian Kompas menulis di halaman dua dengan judul “Anas Sebut Uang Harrier dari SBY”.
Dari sisi tema kedua harian menyajikan tema yang sama yaitu tentang pemberian uang dari SBY untuk pembelian mobil Harrier Anas Urbaningrum. Akan tetapi, kedua harian menampakkan perbedaan yang signifikan dalam berbagai hal.Misalnya, dalam hal penempatan halaman. Pada harian Suara Merdeka judul tersebut diletakkan pada halaman pertama, sedangkan harian Kompas pada halaman kedua. Lalu, dilihat dari font huruf, Suara Merdeka (selanjutnya disingkat SM) lebih besar dan berwarna merah, padahal pada halaman yang sama, judul dicetak dengan warna hitam; sedangkan harian Kompas (selanjutnya disingkat $\mathrm{K}$ ) dicetak dengan font huruf yang lebih kecil dan berwarna hitam. Yang membedakan keduanya juga dapat dilihat dari pilihan katanya, pada SM sudah "memastikan” yaitu dari SBY (Uang Muka Mobil Anasdari SBY); sedangkan K lebih memilih kata sebut (Anas Sebut Uang Harrier dari SBY).Melalui pilihan kata tersebut, $\mathrm{K}$ mengguna kan logika azas praduga tak bersalah, sedangkan SM sudah menyimpulkan. Jika dilihat berdasarkan isinya, SM lebih banyak memuat berita berdasarkan keterangan dari Anas, pengacaranya (Firman dan Adnan Buyung Nasution), KPK, dan sama sekali tidak menyertakan dari sumber SBY; sedangkan pada $\mathrm{K}$ memuat berita berdasarkan keterangan dari pengacaranya, KPK, dan hanya sedikit menyertakan keterangan juru bicara Presiden (Julian A. Pasha). Dari sini tampak keberpihakan SM dan K pada Anas.

\section{Skematik (Superstruktur)}

Skema merupakan alur penyajian berita atau wacana. Alur tersebut menunjukkan bagian-bagian teks itu disusun dan diurutkan sehingga membentuk sutu kesatuan.Ada bagian yang didahulukan dan ada bagian yang mengikutinya, dan ada bagian yang disembunyikan. Skema dalam berita secara umum terbagi menjadi dua bagian yakni: 1) summary yang ditandai dua elemen yakni: judul dan lead (teras berita/ paragraf pertama), 2) story yakni isi berita 
secara keseluruhan (Koentoro, 2008). Berdasarkan skemanya, SM menampilkan judul dan subjudulnya merujuk pada kasus Anas terkait bukan (hanya) dengan kasus Hambalang, melainkan dengan kasus bailout Century; sedangkan pada harian $\mathrm{K}$ memberitakan Anas terkait dengan kasus Hambalang. Harian SM ingin mengaitkan antara kasus Hambalang dan bailout bank Century sebagai satu rangkaian peristiwa yang melibatkan Anas, SBY, dan partai Demokrat. Akan tetapi, setelah dibaca isinya ternnyata tidak menyingung sama sekalai tentang bailout bank Century. Ini artinya antara judul dan subjudul dengan isi tidak terjalin satu kesatuan yang utuh. Sementara, pada harian $\mathrm{K}$ menunjukkan satu-kesatuan yang utuh antara judul utama, subjudul, dan isi yaitu tentang keterlibatan Anas dan (dugaan) SBY dalam kasus Hambalang.

\section{Struktur Mikro: Semantik}

Yang termasuk dalam elemen semantik misalnya latar, detail, dan maksud.Latar adalah bagian berita yang dapat mempengaruhi semantik (arti) yang ingin ditampilkan.Latar yang dipilih menentukan ke arah mana pandangan khalayak akandibawa. Pada berita tentang kasus Hambalang, secara semantik pembaca digiring ke opini bahwa dalam kasus Anas tidak hanya berkaitan dengan kasus Hambalang semata, tetapi menyangkut berbagai masalah, seperti bailout bank century, kongres Partai Demokrat yang melibatkan SBY dan Ibas terutama yang ditampilkan di harian SM; sedangkan pada harian $\mathrm{K}$, beritanya hanya menampilkan kasus Anas yang diduga melibatkan SBY dan Ibas dengan menghadirkan keterangan pengacaranya yaitu Firman, Adnan Buyung Nasution, KPK, dan sedikit juru bicara presiden, yakni Julian A. Pasha.

\section{Sintaksis}

Dalam analisis wacana, koherensi merupakan alat sintaksis yakni pertalian atau jalinan antar kata, proposisi atau kalimat.Koherensi digunakan untuk menghubungkan dua buah kalimat atau paragraf sehingga yang berbeda gagasannya menjadi selaras mendukung gagasan utama yang disampaikan (Koentoro, 2008). Berdasarkan aspek sintaksisnya, harian K lebih menampakkan koheresifitas dibanding SM. Hal itu tampak pada judul utama, subjudul, dan isinya. Selain itu, juga ditunjukkan melalui pembagian gagasan utama yang lebih jelas dengan mebaginya ke dalam tiga bagian/gagasan pokok, yaitu (a) uang muka dari SBY, (b) tuduhan serius, dan (c) KPK akan cek; sementara pada SM hanya satu, yaitu uang muka sehingga "melelahkan" pembaca dalam memahami isi dan alur berpikirnya. Yang kedua, pada harian SM dalam pembagian "subbab" terlalu panjang sehingga koherensi bentuk dan isinya dirasa kurang padu, sedangkan pada harian K lebih pendek sehingga memungkinkan kohesifitas dan koherensi/isinya relatif lebih baik.

\section{Stilistik}

Yang termasuk stilistik misalnya menyangkut aspek leksikon/pilihan kata, praanggapan. Leksikon adalah pilihan kata untuk mendukung makna atau maksud tertentu. Dari sisi stilistik, pilihan kata yang digunakan wartawan pada harian SM dan K menunjukkan keberpihakannya kepada Anas (yang menjadi korban politik). Hal itu tampak dari pilihan kata, misalnya pada harian SM uang muka itu pemberian SBY sebagai ucapan terima kasih, Adnan Buyung Nasution mendesak KPK untuk memeriksa Ibas. Sementara, pada harian K juga menampakkan hal yang sama,yaitu lebih menunjukkan keber-pihakannya pada Anas dan SBY serta Ibas (diduga) terlibat dalam kasus inimelalui pilihan kata/kalimat" Ada data yang mengejutkan, yaitu pemberian uang muka pembelian mobil Harrier dari SBY. "Soal pernyataan Anas ini merupakan tuduhan yang serius 
dan KPK hendaknya menelusurinya.”

\section{Retoris}

Bagian retoris berkaitan dengan ekspresi untuk menonjolkan atau menghilangkan bagian tertentu dari suatu teks. Bagian ini merupakan bagian untuk menampilkan citra visual, misal mengenai kelompok yang ditonjolkan dan kelompok yang dimarginalkan.Yang termasuk ke dalam elemen ini adalah ekspresi, grafis, metafora. Dari aspek retoris, SM lebih menempatkan Anas sebagai aktor/pihak yang dominan terlihat dari penggunaan font yang besar, satu baris penuh, dan berwarna mencolok (merah); sedangkan yang dimarginalkan adalah SBY. Hal ini terlihat porsi pemberitaan yang lebih banyak memberitakan Anas, keterangan pengacara Anas (Firman), penjelasan KPK, dan hanya sedikit (1 kalimat) memuat keterangan kuasa hukum SBY (Palmer Situmorang). Hal yang relatif sama juga ditunjukkan oleh harian K. Pada harian K, pihak yang dimarginalkan juga SBY. Hal ini terlihat dari porsi pemberitaan yang kurang berimbang, yaitu dengan menempatkan keterangan Julian A. Pasha (juru bicara presiden) sebanyak satu kalimat; sedangkan pemberitaaan lainnya lebih banyak memuat keterangan Anas, KPK, dan pengacaranya (Firman dan Adnan Buyung Nasution). Hal yang membedakan dengan SM, harian $\mathrm{K}$ lebih "santun dan proporsional), misalnya dilihat dari fontnya (yang lebih kecil dibanding SM), panjang judul (yang tidak satu baris penuh), berwarna hitam sebagaimana judul berita lainnya, dan "hanya" menempatkan pada halaman kedua (sedang pada SM pada halaman pertama)

\section{Berita tentang Kasus Akil Mochtar}

Berikut ini merupakan salah satu sampel berita/data, yaitu "Kasus Akil Mochtar".Pemilihan sampel data ini mengingat menjadi topik pemberitaan yang hangat dan masa pemberitaannya yang sangat sering. Dari analisis data diperoleh hasil sebagai berikut.

\section{Tematik (Struktur Makro)}

Dari sisi tematik kedua harian (SM dan $\mathrm{K}$ ) relatif sama, yaitu memberitakan tuduhan keterlibatan Akil Mochtar dalam korupsi/sengketa Pilkada di berbagai wilayah. Tema berita yang diangkat menyangkut pembelaan Akil Mochtar, tuduhannya pada Mahfud MD, dan tuntutan jaksa pada Chairun Nisa (anggota DPR dari Partai Golkar) dan Gubernur Gunung Mas, Hambit Bintih. Hanya saja, jika dicermati dari sisi penempatan halaman, SM menempat-kannya pada halaman pertama, sedangkan K pada halaman ketiga; lalu, SM menggunakan font huruf yang sangat besar dan hampir satu baris penuh; sedangkan pada harian $\mathrm{K}$ berita tersebut menggunakan font huruf yang lebih kecil, hanya separuh baris. Dari sisi pilihan kata untuk menulis judul, SM “lebih provokatif”(“Akil Serang Mahfud”), sedangkan pada harian K lebih santun, "Akil Pertanyakan Mahfud”. Sementara, dilihat dari isinya secara umum, SM hanya memberitakan pembelaan Akil, serangannya terhadap Mahfud, dan tuntutan jaksa terhadap Hambit Bintih, Cornelis,dan Choirun Nisa. Sementara, pada harian K, diberitakan tentang pembelaan Akil, pertanyaan keheranan Akil terhadap jaksa tentang peran Mahfud sebagai ketua panelis pada sidang sengketa pilkada Banten, juga dugaan keterlibatan Akil pada sepuluh sengketa pilkada, serta tuntutan jaksa terhadap Chairun Nisa (anggota DPR dari Golkar).

\section{Skematik (Superstruktur)}

Dari aspek skematik dapat dilihat misalnya dari pemilihan judul dan subjudul. Kedua harian (SM dan K) agak berbeda. SM memilih kata yang cenderung "provokatif" (Akil Serang Mahfud), sedangkan pada harian K cenderung lebih proporsional (Akil Pertanyakan Mahfud). Pada bagian subjudul, SM menulis "(Mahfud) (di)Anggap Bertanggung Jawab dan 
Hambit-Cornelis Dituntur 6 Tahun, Nisa 7,5 Tahun; sedangkan pada harian K, subjudulnya adalah "Jaksa KPK Pakai Barang Bukti sebagai Dasar”. Dalam menyajikan berita tentang keterlibatan Akil, SM menggunakan urutan: pembelaan Akil yaitu dengan cara menyerang Mahfud (terutama kasus Pilkada Banten), diselingi berita tentang tuntutan jaksa terhadap Akil, lalu disampaikan bantahan Mahfud (tetapi hanya 1 paragraf), diakhiri dengan berita tentang tuntutan jaksa terhatadap HambitCornelis dan Nisa. Berita lebih difokuskan pada pemberitaan kasus Akil yang (hanya) terkait dengan Pilkada Banten dan Gunung Mas Kalimantan Tengah. Sementara, harian $\mathrm{K}$ dalam menyajikan berita dengan pola urutan: pembelaan Akil dengan sekaligus mempertanyakan kepada Jaksa selama masa persidangan mengapa Mahfud tidak disebutkan dalam dakwaan, Akil tidak bisa menunjukkan keterlibatan Mahfud, jaksa berdasarkan pada bukti (alasan tidak menyebutkan Mahfud), tindak pidana pencucian uang yang dilakukan Akil, keterilbatan Akil pada 10 Pilkada, penerimaan suap terkait Pilkada Banten, dan terakhir memuat berita tentang tuntutan jaksa terhadap Chairun Nisa.

Dari uraian di atas tampak urutan, detail, dan porsi, serta penyembunyian berita, pemfokusan pada kedua harian (SM dan K) tersebut. Dari sisi urutan keduanya cenderung relatif sama, tetapi dari sisi detail lebih detail K dibanding SM; dari sisi porsi SM lebih banyak memberitakan panjang lebar tentang pembelaan Akil, serangan terhadap Mahfud, dan tuntutan jaksa terhadap Hambit-Cornelis dan Nisa. Akan tetapi, tidak menampilkan berita tentang pencucian uang dan tuduhan jaksa terhadap 10 sengketa Pilkada di berbagai wilayah di Indonesia yang dilakukan Akil. SM hanya fokus pada kasus Pilkada Banten dan Gunung Mas Kalimantan Tengah. Sementara, harian K memberitakan lebih "lengkap" mulai dari keterlibatan Akil terhadap 10 sengketa Pilkada, pembelaan Akil, dugaan/kehendak Akil untuk "menyeret" Mahfud, penyuapan yang dilakukan Wawan, Airin, Ratu Atut, tindak pidana pencucian uang, sampai pada tuntutan jaksa terhadap Nisa. Hanya saja, K tidak memberitakan/"menyembunyikan" tuntutan Hambit-Cornelis. Jika dilihat dari porsi pemberitaannya, $\mathrm{K}$ lebih fokus pada pembelaan Akil dan keterlibatannya pada 10 sengketa Pilkada serta pencucian uang, tetapi hanya sedikit (1 paragraf) memberitakan tuntutan jaksa terhadap Nisa.

\section{Struktur Mikro: \\ Semantik}

Secara semantik kedua harian (SM dan K) menampilkan latar yang kurang lebih sama, yaitu keterlibatan Akil dalam tindak pidana korupsi. Bedanya, harian $\mathrm{K}$ di samping menggunakan latar korupsi Akil juga tindak pidana pencucian uang. Menyangkut detail, harian $\mathrm{K}$ dinilai lebih detail dibandingkan dengan SM baik dari sisi aspek (aktor) yang ditampilkan maupun isi/substansi (pencucian uang, sengketa10 pilkada). Dari sisi maksud/opini yang ingin dibangun oleh wartawan SM dan K relatif sama, yaitu bahwa tindakan korup yang dilakukan oleh Akil tidak hanya dia sendiri yang "bermain”, tetapi merupakan kejahatan mafia, kolektif, dan bersifat kausalitas. Misalnya, dengan menyebut Mahfud sebagai pihak yang ikut terlibat (khususnya untuk kasus Pilkada Banten); sedangkan yang bermakna kasalitas yaitu bahwa tindakan Akil tidak akan (mungkin) terjadi jika Wawan, Ratu Atut, Airin, Cornelis, Hambit Bintih, dan Nisa tidak (berusaha) melakukan penyuapan. Karena kasus tersebut melibatkan tidak hanya satu orang, dapat disebut sebagai kejahatan kolektif (jamaah).

\section{Sintaksis}

Dari sudut sintaksis, khususnya aspek urutan berpikir dan tata bahasa (ejaan, tanda baca) harian $\mathrm{K}$ cenderung lebih runtut dan mudah dipahami alur berpikirnya dibandingkan dengan harian SM. Pada harian SM terdapat paragraf yang dinilai mengganggu alur berpikir, yaitu terletak pada uraian pembelaan Akil terselip dua paragraf yang menguraikan tuduhan dan 
tuntutan terhadapnya. Dalam hal penggunaan tanda baca dan fungsi (Subjek, Predikat misalnya) harian K cenderung lebih sesuai kaidah tata bahasa dan sistematis dibanding SM. Pada harian SM, misalnya ditemukan kalimat yang tidak bersubjek (Menuntut, supaya majelis hakim...). Pada harian SM juga banyak digunakan kata penghubung kemudian, lalu, lebih lanjut, sementara itu.Banyaknya penggunaan kata penghubung dalam sebuah paragraf dapat dipandang mengganggu alur dan kelancaran berpikir.Sebab, dengan begitu antara kalimat satu dan kalimat lainnya seolah-olah hanya ditempelkan/dipaksakan untuk dirangkai.Sementara, harian K lebih banyak mengembangkan paragraf dengan menggunakan kata kunci (misal anehkeanehan seperti dalam kalimat Aneh bagi saya di semua uraian Pilkada yang didakwakan kepada saya tidak berani menyebutkan bahwa ketua panelnya adalah Mahfud M.D. Keanehan itu dia nyatakan saat membacakan nota keberatan (eksepsi). Dengan cara seperti yang dilakukan wartawan harian $\mathrm{K}$ gagasan menjadi "mengalir, lancar" sehingga gagasannya mudah dipahami. Dari sisi kaidah, pengembangan paragraf dengan menggunakan teknik pengembangan kata kunci dinilai lebih baik daripada (banyak) menggunakan kata penghubung.

\section{Stilistik}

Secara stilistik, harian SM memilih kata serang (Akil serang Mahfud). Pilihan kata serang dapat dimaknai bahwa wartawan SM cenderung provokatif dan menghendaki agar Akil bukan satu-satunya terdakwa dalam kasus Hambalang, tetapi ada orang lain, yaitu Mahfud M.D. Artinya, kasus ini hendaknya dibuka secara luas dan transparan. Hal ini berbeda dengan harian $\mathrm{K}$ yang lebih memilih kata mempertanyakan
(Akil Pertanyakan Mahfud).Wartawan harian $\mathrm{K}$ menulis sesuai dengan yang dikatakan Akil dalam eksepsinya.Dengan demikian, dapat dimaknai bahwa harian $\mathrm{K}$ lebih objektif, cenderung netral, dan tidak provokatif. Harian K lebih banyak memilih kata menyebutkan, menjelas-kan, mempersoalkan, pencucian uang, sengketa Pilkada, mengadili yang cenderung bermakna denotatif dan objektif; sedangkan pada harian SM lebih memilih kata menyerang, menganggap (Mahfud terlibat), jaksa PU tidak berani (mencantumkan nama Mahfud), menyerang KPK yang cenderung bernuansa konotatif, provokatif, dan subjektif. Dilihat dari sisi keberpihakan melalui pilihan kata dan isinya, harian $\mathrm{K}$ cenderung lebih netral dibandingkan dengan harian SM.

\section{Retoris}

Aspek retoris yaitu bahwa wacana/teks dapat dilihat dari font hurufnya, warna, panjang pendeknya, ilustrasi gambar, pemfokusan sebagai upaya mendeskripsikan pihak yang dominan dan yang dimarginalkan. Berdasarkan hal tersebut, harian SM dalam menulis judul (Akil Serang Mahfud) menggunakan font huruf yang sangat besar, ditempatkan pada halaman pertama, dan hampir satu baris penuh; sedangkan pada harian $\mathrm{K}$ ditulis dengan font yang sedang, setengah baris, dan diletakkan pada halaman 3. Judul pada SM cenderung provokatif, sedangkan harian $\mathrm{K}$ tidak provokatif (denotatif), yaitu Akil Pertanyakan Mahfud. Bagian yang ditonjolkan untuk SM adalah serangan Akil terhadap Mahfud dan kasus suap Pilkada Banten dan "menyembunyikan" tindak pidana pencucian uang dan kasus susap sengketa di 10 Pilkada. Untuk harian K, menonjolkan kasus suap yang membelit Akil mulai dari kasus suap Pilkada Banten, Gunung Mas Kalimantan tengah, pencucian uang, sampai pada tuntutan jaksa terhadap Nisa. Harian K dalam hal ini dalam menyajikan berita cenderung proporsional, berimbang, dan objektif. Dari sisi grafis, SM 
menampilkan foto Akil, Hambit Bintih, dan Chairun Nisa dengan ukuran besar, sedangkan pada harian $\mathrm{K}$ hanya menampilkan Akil di persidangan. Dari sini, SM seolah ingin memberitahukan kepada pembaca, "Inilah lho wajah koruptor yang bejat (karena pejabat tinggi yang semestinya menjaga kewibawaan lembaga peradilan yang dipimpinnya), sedangkan harian $\mathrm{K}$ menyajikan gambar secara wajar dan datar.

\section{SIMPULAN}

Dari uraian di atas dapat dicatat beberapa hal. Pertama, penelitian analisis wacana kritis dengan model Teun van Dijk dapat diperluas dan diperdalam baik terhadap objek maupun jangkauan penelitiannya. Sebab, penelitian ini masih terbatas sumber data dan jangkauannya. Kedua, secara umum kedua harian samasama berusaha untuk menyajikan berita secara objektif dan berimbang. Akan tetapi, hal yang tak terhindarkan pada teks yang ditulisnya mencermin ideologi tertentu yang berbeda, pada harian SM, misalnya cenderung memilih ideologi yang kasar, provokatif, dan konotatif/figuratif.

Ekspresi ideologi tersebut, misalnya dapat dilihat pada pilihan kata yang cenderung kasar, seperti mengancam, menyerang, memanggil paksa, menyeret, menembak. Ketiga, sebagai "lembaga" bisnis/industri antara SM dan K cenderung memiliki ideologi yang berbeda. SM cenderung lebih "berideologi" pasar, sedangkan pada harian K lebih pada ideologi idealisme pers yang objektif, netral, dan berimbang.Keempat, dari dimensi kekuasaan (simbolik), harian SM cenderung menjadi "oposisi” sebagai pihak yang didominan-kan, sedang pihak pemerintah sebagi pihak yang “dimarginalkan” (kasus Anas, Century).

Sementara, harian $\mathrm{K}$ menempatkan pihak yang dominan/marginal lebih didasarkan pada kondisi objektif di lapangan yang berbasis data dan keterangan yang dari narasumber yang cenderung netral, seperti pengamat, warga, dan akademisi; tidak didasarkan pada keterangan yang cenderung subjektif, seperti dari para politisi. 


\section{DAFTAR PUSTAKA}

Aan, Munawar Syamsuddin. 2013. Resolusi Neo-Metode Riset Komunikasi Wacana. Yogyakarta: Pustaka Pelajar.

Adji, Indriyanto Seno. 2011. "Analisis Wacana Kritis Model van Dijk: "DPR dan KPK di Mata Kompas” (Tesis). Depok: Universitas Indonesia.

Al-Barbasy, Ma'mun Morud. 2013. Anas Urbaningrum Tumbal Politik Cikeas. Jakarta: Pijar Ilmu.

Badara,Aris. 2012. Analisis Wacana: Teori, Metode, dan Penerapannya pada Wacana Media.

Eriyanto. 2000. Kekuasaan Otoriter dari Gerakan Penindasan Menuju Politik Hegemoni: Studi atas Pidato-pidato Politik Soeharto. Yogyakarta: Pustaka Pelajar.

Eriyanto. 2011. Analisis Wacana: Pengantar Analisis Teks Media. Yogyakarta: LKIS.

Fashri, Fauzi. 2007. Penyingkapan Kuasa Simbol. Yogyakarta: JUXTAPOSE.

Fairclough, Norman. 1995. Crtical Discourse Analysis: The Critical Study of Language. London: Longman.

Faisal, Moch. 2003. Language and Power (Terjemahan Indah Rohmani). Malang: Boyan.

Fiske, John. 1990. Cultural and Communication Studies (Terjemahan Idi Subandi Ibrahim, Ed.). Yogkarta: Jalasutra.

Handayani, Christina S. dan Ardhian Novianto. 2004. Kuasa Wanita Jawa. Yogyakarta: LKIS.

Ibrahim, Abdul Syukur. 1984. Panduan Penelitian Etnografi.Surabaya: Usaha Nasional.

Ibrahim, Syukur (Ed.) 2007). Ancangan Kajian Wacana. (terj). Yogyakarta: Pustaka Pelajar.
Ibarahim, Abdul Syukur. 2009. Metode Analisis Teks dan Wacana (terj). Yogyakarta: Pustaka Pelajar.

Ihsan, A. Bakir. 2012. Politik Tak Hanya Kekuasaan. Jakarta: Expose.

Ismail. 2013. Ironi dan Sarkasme Bahasa Politik Media. Yogyakarta: Pustaka Pelajar.

Larrain, Jorge. 1996. "The Concept of Ideology”. (terj. Ryadi Gunawan). Yogyakarta: LKPSM.

Latif, Yudi dan Idi Subandi Ibrahim. 1998. Bahasa dan Kekuasaan. Jakarta: Mizan.

Linda Thomson dan Shan Wareing. 2007. Language, Society, and Power (Terjemahan Abdul Syukur Ibrahim). Yogyakarta: Pustaka Pelajar.

Margono, Erwin. 2003. “Analisis Wacana Kritis Tionghoa Indonesia (Studi Kasus: Organisasi dan Teks Pemberitaan Imlek Harian Kompas Antara tahun 1965 - 2003”. Tesis FISIP Universitas Indonesia, Jakarta.

Moedjanto. 1987. Konsep Kekuasaan Jawa: Penerapannya Oleh Raja-Raja Mataram.Yogyakarta: Kanisius.

Noorsalim, Mashudi dan Muridan S. Widjojo. 2004. "Bahasa Negara Versus Bahasa Gerakan Mahasiswa (Kajian Semiotik atas Teks-Teks Pidato Presiden Soeharto dan Selebaran Gerakan Mahasiswa)”. Jakarta: LIPI Press.

Santoso, Anang. 2009. Bahasa Perempuan. Jakarta: Bumi Aksara.

---------. 2012. Studi Bahasa Kritis: Menguak Bahasa Membongkar Kuasa. Bandung: Mandar Maju.

Stone, Clarence. 1998. "Power and Social Complexity”. Dalam Robert J. Waste(Ed.), Community Power: Directions for Future Research. London: Sage Publications. 
Sudibyo, Agus. 2006. Politik Media dan Pertarungan Wacana. Yogyakarta: LKiS.

Sudaryanto. 1990. Menguak Fungsi Hakiki Bahasa. Yogyakarta: Duta Wacana University Press.

Suharyo, dkk. 2013. "Bahasa dan Kekuasaan: Antara Pertarungan
Wacana dan Perebutan Kekuasaan (Studi Kasus Perilaku Politisi di Media Massa”. Laporan Penelitian). Semarang.

Syamsuddin, Munawar. 2008. Makiwa (Metode Analisis Kritis Komunikasi, Interpretasi, Wacana). Solo: UNS Press.

Lampiran 1. Metode Analisis Wacana Kritis menurut van Dijk (via Badara, 2012; Eriyanto, 2011)

\begin{tabular}{|c|c|c|}
\hline $\begin{array}{l}\text { STRUKTUR } \\
\text { WACANA }\end{array}$ & $\begin{array}{c}\text { HAL-HAL YANG DIANALISIS } \\
\text { PADA TEKS (TERTULIS SECARA } \\
\text { NYATA) }\end{array}$ & $\begin{array}{l}\text { ELEMEN- } \\
\text { ELEMEN }\end{array}$ \\
\hline \multirow{2}{*}{ MAKRO } & JUDUL DAN ANAK JUDUL & $\begin{array}{l}\text { Subjek, } \\
\text { Predikat, } \\
\text { Objek } \\
\end{array}$ \\
\hline & $\begin{array}{l}\text { TEMATIK } \\
\text { Tema/Topik Utama yang ditonjolkan } \\
\text { oleh keseluruhan teks }\end{array}$ & Tema/Topik \\
\hline $\begin{array}{l}\text { SUPER- } \\
\text { STRUKTUR }\end{array}$ & $\begin{array}{c}\text { SKEMATIKA } \\
\text { Kerangka; Framing; Alur; Pola; Logika }\end{array}$ & $\begin{array}{l}\text { Skema: Prolog- } \\
\text { Dialog-Epilog- } \\
\text { Resume }\end{array}$ \\
\hline \multirow{4}{*}{$\begin{array}{l}\text { STRUKTUR } \\
\text { MIKRO }\end{array}$} & $\begin{array}{l}\text { SEMANTIKA } \\
\text { Arti dominan di lokal teks/ makna yang } \\
\text { ingin disampaikan; (bukan dominan } \\
\text { yang lain) } \\
\text { Misal mendominankan detil yang satu, } \\
\text { meminorkan yang lain. }\end{array}$ & $\begin{array}{l}\text { Latar; Detil } \\
\text { Praanggapan } \\
\text { Maksud } \\
\text { Nominalisasi }\end{array}$ \\
\hline & $\begin{array}{l}\text { SINTAKSIS } \\
\text { Strategi } \\
\text { Politik/Ideologi/KekuaaanSusunan } \\
\text { Kalimat }\end{array}$ & $\begin{array}{l}\text { Bentuk } \\
\text { kalimat, } \\
\text { koherensi, } \\
\text { Kata Ganti }\end{array}$ \\
\hline & STILISTIKA & $\begin{array}{l}\text { Leksikon } \\
\text { Kosa Kata }\end{array}$ \\
\hline & RETORIKA & $\begin{array}{l}\text { Grafis } \\
\text { Metafora } \\
\text { Ekspresi }\end{array}$ \\
\hline
\end{tabular}

